\title{
FINANCIAL REPORTING IN EDUCATION INSTITUTIONS THE IMPLICATIONS OF THE TRANSITION TO ACCRUAL ACCOUNTING
}

\author{
Iuliana Cenar ${ }^{1}$
}

ABSTRACT. At the beginning of the third millennium, the role of accounting changed fundamentally, including in terms of the major intervention in collecting and treating information used to achieve an efficient management that will support the future evolution of entities, including institutions of higher education. Accounting is called to ensure veridical and objective information for all the "actors" who play their role on the scene created by the university of the future, its internal and external environment.

As the language of business, accounting shapes information in the form of syntheses, in which financial reporting is discerned. In the public sector, the information's structure and content was subjected to major transformations, generated by the complementary of cash accounting with accrual accounting and the generalization of double entry accounting, changes that became applicable at the beginning of 2006. This paper approaches aspects regarding the purpose of the accounting information processing, namely: the role of higher education institutions in supplying public capital, seen as a development factor; the structure, objectives and usefulness of financial statements in the public sector; the effects of using the two accounting models, cash and accrual, on the quality of financial reporting.

Key words: financial reporting, education institutions, cash accounting, accrual accounting

Jel codes: $M 41$

\section{Introduction}

In the era of modernism, when things are changing at the speed of lighting, talking about history may seem outdated, but by researching the past, we acquire information that guide our present, as well as our future. As professor N. Feleaga said, the past is never dead and "without historical foundation, our knowledge is precarious and judging current phenomena is incomplete and lacking in maturity" (B Pendorf quoted by D. Rusu, 1980).

Identifying ways to improve financial reporting in the public sector requires knowing its evolution, the changes it was subjected to when cash flow accounting was supplemented with accrual accounting.

Deciding properly and efficiently means being permanently well informed. Making economic decisions and assessing past activities is based primarily on accounting information (E. Horomnea, 2008). The information support of accounting creates a superior base for elaborating action plans, so that it's possible to identify long-term competitive advantages.

Any decisional process has information and knowledge as attributes, and accounting is considered the informational support in substantiating decisions. At the level of the higher education institutions, the supply of accounting information had to adapt to the demand, which is more complex and diverse. The method with the largest impact in this regard was to supplement cash accounting with accrual accounting in public institutions. The primary communication mean of accounting information to various categories of users are the financial statements.

\footnotetext{
1 “1 Decembrie 1918” University of Alba Iulia, Faculty of Science, Romania, e-mail: cenar_iuliana@uab.ro
} 
The paper presents the implications generated by the transition to accrual accounting on the content and characteristics of financial reports prepared by higher education institutions. We aim to achieve a comparative analysis of the structural and qualitative content of the accounting information presented in the financial statements of higher education institutions. This way, the accounting's progress can be assessed on the segment of financial reporting, their specific in higher education, as well as finding ways to meet the increasingly complex information requirements imposed by the evolutionary pace of human society.

\section{Research methodology}

To research means to study in detail and systematically in order to know something. In turn, the methodology describes the set of research methods in a certain science or, the science of conducting a research.

The methodological support of this research was the specialized literature, the segment of financial reporting (which made it possible to analyze this segment), the relevant legislation, as well as the factual documentation at a higher education institution. The international accounting references that target the preparation and presentation of financial statements in the public sector were taken into account also.

The working instruments for gathering and interpreting data includes: synthesis, the structured observation (characterized by the fact the research object is precisely delimited), analysis of documents and of the bibliographic sources, comparison conducted at the overall level of financial reporting, but also on their each component, including at the level of the incorporated elements. The qualitative approach was not excluded either, being based on the interpretation and explanation of the financial reporting's structure.

In terms of time, the conducted research is longitudinal because we analyzed the evolutionary changes that the financial reporting of higher education public institutions we subjected to in recent years, when national accounting rules intertwined increasingly with international rules.

\section{Literature review}

The subject of financial reporting is one frequently encountered in literature.

The public institution is a complex reality, a system permanently subjected to internal changes, which must adapt at the same time to the external environment characterized by diversity and incertitude (Berheci, 2010). The international accounting norms use the concept of entity to name the institutions whose main objective is to achieve complete and quality public services.

The reporting entity is the accounting entity that has information users, and financial statements are the main source of financial information for the users who are in the position to make decisions regarding management responsibility, the ability to pay debts, the identification of moments favourable to making certain transactions, the standardization of activities, etc.

In the preface to the general framework for preparing and presenting financial statements is mentioned that "businesses around the world prepare financial statements to present them to external users". Financial statements are the core of accounting syntheses, being the most important part of the financial reporting process and the main source of financial-accounting information for those who are interested (Berheci, 2010).

International, as well as national accounting rules (Accounting law no. 82/1991 republished, Order of the Ministry of Public Finance no. 1917/2005) approach the complex issue of financial statements, namely: the compulsoriness of preparing and presenting them, the structure of financial statements, the content of their components, the principles that underpin them, the valuation rules of different components, as well as the preparing, approving, auditing and publishing rules.

Thus, the accounting reporting framework is created, which guides regulatory bodies in developing norms, helps those who prepare financial statements, helps the auditors and users in 
treating all the aspects related to production, use and certification of accounting information (Todea, 2009).

In Europe, approaching financial reporting is a process that acquires special attention starting with the harmonization of the legal and economic framework for the member countries of the European Union.

The general framework for preparing and presenting financial statements indicate that their main objective is to supply a basis for presenting general financial statements in order to be able to ensure comparability over time with the financial statements of the entity for the previous periods and comparability in space with the financial statements of other entities. The financial statements must reflect the entire unfolded activity, as well as the situation at a given moment, the size of the real and monetary flows derived from the relationships with the outside and from internal activity (Matis, 2007), should "show the results of the entity's management, including their management of the resources allotted to them" (Feleaga and Malciu, 2002).

In the opinion of professor Horomnea, achieving the crucial objective of accounting (the accurate picture of the financial position, financial performance and changes in the financial position) doesn't imply focusing on details, but rather on aggregating them in global images that capture current life and the prospects of the whole.

M. Bolos (2006) positions the reform of public accounting over the three reforming waves of accounting, the logic of the path for modelling information in the public sector, emphasizing the transformations induced by the transition from the cash model to the accrual model, with detailed exposure of the implications, including over financial statements, which include "the portfolio" of available information for users. The special importance of financial statements is given by the fact that in most cases the provided information is the only one that the users have access to and is the basis of economic decisions.

At global level, we are going through a period full of risks and opportunities, marked by geopolitical, economic and professional interests, which impose the necessity of finding a solution and a consensus that will benefit everybody all around the world (Bota Avram, 2009).

Financial reporting in the public sector is the subject of the International Public Sector Accounting Standards Board (IPSASB), which has issued in this regard the following standards:

- IPSAS 1 "Presentation of financial statements" prescribes the manner in which general purpose financial statements should be presented in order to ensure comparability with the entity's own financial statements of previous periods and with the financial statements of other entities. General purpose financial statements respond to the information needs of the users who are not in a position that allows them to request financial statements adapted to their needs.

- IPSAS 2 "Cash flow statements" present the importance and providing manner of information about the historical changes of cash and cash equivalents. This information allows the users to determine how the public institution raised the necessary cash to finance its activity and how the cash was used.

- IPSAS for cash accounting - According to cash accounting, financial reporting establishes the directives that are applied to entities that prepare general purpose financial statements in accordance with cash accounting. Its purpose is to ensure the consistent and transparent reporting of cash inputs, cash payments and cash balances of the entities.

The international accounting standards also aim to establish a unitary basis for preparing statements in order to create the premises for conducting comparative analyses between them in terms of time and space; to adapt national standards to international ones and not to overlap them, the scope of international standards has to circumscribed for significant elements, taking into account the fact that these standards don't become coercive. 


\section{The public capital provided by universities}

The capital acquired through higher education public institutions is a component of public capital, which, in its turn, is a binder and a support for the other three growth factors, namely physical capital, technical capital, which generates competitive advantages, and human capital.

The existence of education as a public service implies three identification criteria:

- The organic criterion (in terms of its management by a public person (university) following a decision made by the public authority);

- The material criterion takes into account the end result of higher education by comparing it to the interests of the education's beneficiaries;

- The legal criterion - education has the rules of administrative law, which implies rigorous legal patterns intended to protect and satisfy the general interests of society.

Among the principles of action of public services is the transparency and accountability principle (Profiroiu, 2001). It implies that all users have the right to systematic information over public services.

Transparency must be conceived as a condition of dialogue, but also as a control instrument of the public services' action, including higher education, by the users.

In turn, financial statements must provide an accurate, real and "transparent" picture of the financial position, financial performance and treasury flows.

Beyond the various perceptions over the accurate picture and according to international standards of accounting specific for the public sector, an accurate statement implies:

- Selecting and applying accounting policies;

- Presenting information, including accounting policies, in a manner that will ensure relevance, correctness, comparability and relevance of information;

- Supplying additional information when the IPSAS requirements are insufficient to provide users with the understanding of the impact of certain events or operations over the financial situation and financial performances of the entity.

Therefore, the information addressed to users must meet the quality attributes, such as intelligibility, relevance in influencing the users' decisions, credibility (neutrality, prudence, and completeness), and comparability in space and over time.

The document support provided by accounting in this regard is represented by the financial statements that address to a wide range of users: taxpayers, members of the assembly (councillors, parliamentarians), creditors, suppliers, mass-media, and employees.

Currently, the public service of education is subjected to competition, in relation to which it must be positioned. Competition started to develop at the same time with the opportunity to chose and is manifested between general interest and private interest, between methods used to put it into practice, between ministries and services (in the sense of establishing priorities and destinations for financial resources), but also between different services aimed at the actual higher education.

Higher education is faced today with the significant evolutions of its mission (research, education), with structures that must be remodelled, but it must prove its efficiency and ability to fulfil taken missions and the aimed objectives. Therefore, higher education institutions must learn to manage changes, and not learn only how to manage something that already exists.

\section{Structure, objective and utility of financial statements in the public sector}

Initiating any cognitive process in observing phenomena and economic processes is followed by organizing information in relation to practical necessities, in a certain form of presentation, recovery and hoarding of accounting products, materialized in financial statements. The permanent changing and ranking of the users' needs has impregnated the adequate evolution of informational media, called to generate an information system capable to satisfy the requirements imposed by the socialization of accounting. Without information and an accurate reporting system, public institutions will not have adequate resources for a proper management. 
The purpose of public institutions preparing financial statements is to obtain and supply (following the completion of a centralized accounting) useful information to substantiate decisions and to justify how financial resources are used. The usefulness of information is proven by its content: the nature of resources and who they are raised, allocations in accordance with the provisions of the approved budget, the use of resources, what cash needs were covered, the ability to pay debts and commitments, etc.

In the accounting doctrine of the last decades, what we call financial statements has evolved under the names (Horomnea, 2008): reporting, periodic synthesis calculations, closing document for the financial years, statements of financial-accounting reporting, documents of synthesis and accounting-financial reporting, annual accounts.

L. Feleagă promotes the following significations of the representative documents for the terminus of accounting:

- Annual accounts include: balance sheet, profit and loss accounts and annex;

- Synthesis documents include, in addition to the annual accounts, the management report, the financing framework and the auditor's report;

- Financial statements represent an equivalent of synthesis documents;

- The annual report includes, in addition to the synthesis documents, general information about the entity and an analysis of its activity.

In literature we can also find the terminology of accounting syntheses, which names a complex structure with the following components: balance sheet, the income account, cash flows statement, the statement of changes in the structure of assets/capitals, annexes/explanatory notes and accounting policies, costing, the system of checking balances, comparative analysis and estimated calculus (D. Rusu, 1980).

International accounting norms specific for the public sector present differently the structure of financial statements depending on the basis of preparing financial statements, namely:

- Accrual accounting. In this case, financial statements will include: the financial position statement; financial performance statement; statement of changes in net assets/equity; cash flows statement; accounting policies and notes to financial statements.

- Cash accounting: the primary financial statement is Encashment and cash payments statement.

An entity may prepare financial statements for other parties also (management bodies, legislative bodies, etc.). These may request financial statements for specific informational needs. It is the reason why such statements are called financial with a special purpose.

It seems that only a brief foray into literature reveals the complexity of the issue related to financial reporting, starting with the structural aspects and continuing with the aspects generated by transitioning from the cash model to the accrual model, including in terms of the accounting of higher education institutions.

In general terms, the objective of financial statements is to provide information about the financial position, the financial performance and the treasury flows of an entity, information that must help users in making decisions about allotting resources.

Being one step closer to the specific and running conditions of the activities of public institutions, IPSAS 1 "Presentation of financial statements" stipulates that the major objective of financial reporting in the public sector is to ensure useful information to substantiate decisions and to justify the use of resources put at the disposal of the unit by providing information:

- regarding sources, allocations and use of financial resources;

- regarding the way units financed their activity and ensured the cash requirements;

- necessary for assessing the ability of the unit to finance its own activity and to cover debts and commitments;

- regarding the financial conditions of the enterprise and their changes; 
- regarding necessary aggregates in assessing the unit's performances expressed in the cost of service, efficiency and skills.

Financial statements show if the resources were obtained and used in accordance with:

- the adopted budget law;

- the provisions of the contracts signed legally, including the financial limits established by a competent legal authority.

The financial statements prove their usefulness through the following features (Matis, 2005)

- they represent a mean of management and analysis and may be named the entity's mirror;

- they represents the primary mean of information of various users (s.n.) regarding the operations and transactions unfolded in the reporting period and their effect over financial balance, namely over the recorded results;

- they are a basis for calculating the macroeconomic and sectorial indicators, and for preparing forecasts with the help of statistical data they provide about the assets and the results of all the legal entities.

A feature of units in the public sector is the budget limitation, imposed by allocations or budget authorizations approved according to law, so that financial reporting aims to provide information about obtaining (attracting) resources and using them in accordance with the approved budget.

\section{Cash accounting versus accrual accounting and their effects over financial reporting}

Basically, the characteristics of cash accounting and accrual accounting are known and disseminated, and the latter had been gradually implemented in the public sector in Romania between 2002 and 2005. This was mainly done because, if we analyse each segment of public services, we can see various ways to transpose commitment in accounting (a future research regarding this aspect at the level of higher education institutions is not excluded). In a pragmatic manner and by relating only to the last component of the accounting processing cycle - financial reporting, we will present the structure of financial reporting under the two accounting models:

Table no.1

\section{The structure of financial reporting at the level of higher education institutions Cash model and accrual model}

\begin{tabular}{|l|l||}
\hline \multicolumn{1}{|c|}{ Cash accounting } & \multicolumn{1}{c|}{ Accrual accounting } \\
\hline Balance sheet & Balance sheet \\
\hline $\begin{array}{l}\text { Budget execution account } \\
\text { Statement regarding the execution of the } \\
\text { employed expenditure budget }\end{array}$ & Budget execution account \\
& $\begin{array}{l}\text { Earnings account } \\
\text { Cash flow statement } \\
\text { Statement of changes in net assets/equity }\end{array}$ \\
\hline \multicolumn{2}{|c||}{ Annexes } \\
\hline $\begin{array}{l}\text { - Synthetic indicators of the income and expenditure budget's execution } \\
\text { - The report regarding the financial audit } \\
\text { - Available from special purpose means } \\
\text { - Fixed assets statement / Depreciable and unredeemable fixed assets } \\
\text { - Detailed expenses (according to economic classification) }\end{array}$ \\
\hline Claims and debts statement & Outstanding \\
\hline \multicolumn{2}{|c||}{} \\
\cline { 2 - 2 } & $\begin{array}{l}\text { Statement of assets and debts of central } \\
\text { government public institutions at the end of the } \\
\text { year }\end{array}$ \\
\hline
\end{tabular}




\begin{tabular}{|c|c|}
\hline Cash in bank statement & \\
\hline "Debtors" statement & \\
\hline \multirow{3}{*}{$\begin{array}{l}\text { Revenues and expenditure at the end of the } \\
\text { year }\end{array}$} & \\
\hline & Accounting policies \\
\hline & $\begin{array}{l}\text { Explanatory note regarding the variation of } \\
\text { different balance sheet items }\end{array}$ \\
\hline $\begin{array}{l}\text { Explanatory report on the achievement of } \\
\text { the revenue and expenditure plan }\end{array}$ & $\begin{array}{l}\text { Explanatory report on the achievement of the } \\
\text { revenue and expenditure plan }\end{array}$ \\
\hline $\begin{array}{l}\text { Internal audit report regarding financial } \\
\text { statements }\end{array}$ & $\begin{array}{l}\text { Internal audit report regarding financial } \\
\text { statements }\end{array}$ \\
\hline
\end{tabular}

The architecture of financial reporting is obviously different, being "enriched" with new components (earnings account, cash flow statement, statement of changes in net assets/equity) at the same time with the orientation towards internationalising public institutions' accounting and towards the needs of all the categories of users of accounting information.

The construction of financial reporting according to the cash model, subordinated to the state's interest, provided the opportunity to monitor budget allowances, to comply with budgetary discipline, to verify the performance of statistical indicators at central level.

The balance sheet is the situation that provides information regarding the assets, debts and equity of an entity and their relationships at a given moment, "as reflections of economic resources on one hand, and of the financing structure on the other hand, sprang from the users' needs" (Bota Avram, 2009).

As a result, "the financial position is defined by the economic resources that it controls, by the financial structure of assets, debts and equity, by the liquidity and solvency of the economic values and by the ability to adapt to changes in the environment where it runs its activity" (Ristea, 2005).

Its role is to validate the principles of dual representation and double entry on which accounting is built. The duality of the representation implies the material aspect represented by goods and monetary values, as well as the legal aspect, reflected in their sources of origin.

Table no. 2

Balance sheet component according to cash model and accrual model

\begin{tabular}{||l|l||}
\hline \multicolumn{1}{|c|}{ ASSETS } & \multicolumn{1}{|c|}{ ASSETS } \\
\hline $\begin{array}{l}\text { Fixed assets and lands, small inventory, other } \\
\text { assets }\end{array}$ & Non-current assets \\
\hline $\begin{array}{l}\text { Money resources, settlements, expenditure and } \\
\text { materials }\end{array}$ & Current assets \\
\hline \multicolumn{1}{|c|}{ LIABILITIES } & \multicolumn{1}{c|}{ OWN DEBTS AND EQUITY } \\
\hline Funds & $\begin{array}{l}\text { Non-current debts } \\
\text { Current debts }\end{array}$ \\
\hline $\begin{array}{l}\text { Funding from the budget, own revenues, } \\
\text { settlements, other sources }\end{array}$ & Net assets - equity \\
\hline
\end{tabular}

Therefore, the accounting balance sheet prepared on the basis of cash includes elements of the earnings account (revenues, expenditure), which, subsequently, were separated in a different component of financial statements, namely the earning account. Also, in this case, the criteria of liquidity and exigibility can't be used to systematize balance sheet elements.

The balance sheet prepared in accordance to the cash model highlights the relation: 
Fixed assets and lands, small inventory, other assets + Money resources, settlements, expenditure and materials $=$ Funds + Funding from the budget, own revenues, settlements, other sources

and the list type of balance sheet systematizes patrimonial structures as follow: assets, debts, equity, and its end result is the presentation of the net statement of assets:

\section{(Non-current assets + Current assets $)-($ Non-current debts + Current debts $)=$ Net assets/Equity}

Given the previous mentions and the equation specific to the matrix of the balance sheet in the form of a list as a financial-mathematic relation (total assets - debts $=$ net assets), the elements that compose the net asset are found separately in its structure, namely: reserves and funds, earnings.

Statement of changes in net assets/equity. The existence of variations between assets and commitments involves the reporting of the net assets' residual value, a positive value being interpreted as a net source that may be used in the future to cover various public services, therefore as investment in the entity that prepares the report; a negative value of the net assets reflects the amount of future samplings, amount that is already committed to paying off current obligations.

This component justifies its necessity through the fact the variation of the fair value of elements in the balance sheet is not recognized in the earnings account, but is recognized at the level of the equity elements. Here emerges the need for an overall approach of the result, generated by the changes in equity during the financial year.

The information needs of the financial statements' users are becoming increasingly more complex, the users being interested in the value of the entity's net assets, as well as in the changes that generated influences over the net statement.

If in Romania there is a pre-established format for the balance sheet, IPSAS 1 "Presentation of financial statements" doesn't establish the order or format in which the elements must be presented.

The role of the earnings account is to explain how the earnings in the balance sheet were obtained. This way, it becomes possible to know the effects of different activities, transactions and events over the achievement level of established objectives by financial institutions (which start from the requirement to provide quality public services).

Thus, performance is measured in terms of earned revenues and consumed resources, and not in terms of received and paid cash. The earnings bring other "intermediate capital accumulations" (Bolos, 2006), namely the operational result (which includes the elements: revenues from economic activities, funding, subsidies, transfers, special purpose budgetary allocation, other operating incomes; as well as: wages, subsidies and transfers, stocks, supplies, works and services provided by third parties, capital spending, depreciation and other operating expenditure), the financial result and the extraordinary result. The end result is measured in surplus or deficit, including the result of the budgetary execution, as well as the one of the non-budgetary execution.

According to IPSAS 1, the entity should present, either in the contents of the financial performance statement, or within the notes, an analysis of expenses by using a classification based on the nature of the expenses or on their function within the entity's activity.

In our country was adopted the solution of presenting expenses in annexes according to the functional classification in the budget execution account and according to their nature (economic classification).

We noticed the use of the term "patrimonial", which was rather "challenged" in literature lately given its legal orientation and the scope of the patrimony in this regard.

The budget execution account reflects the actual size of the economic and social activities that consume resources and produce results. If the budget is a forecast document, which estimates 
the size of the indicators, the budget execution account presents the fulfilment level of the indicators stipulated in the document.

Although present in both accounting models, it should be mentioned that in the case of cash accounting, the forecast document consisted exclusively of "cash" information, as follows:

- expenditure: approved budget appropriations, final budget appropriations, payments, actual expenses;

- incomes: approved provisions, final provisions, encashment.

The annual "solving" of the expenses and revenues collected along the way take a more primitive procedural form, meaning there is no special results account, the expenses being simply deducted from revenues, and the surplus (or deficit) is transferred to the bookkeeping of the following year (Dragan, 2001).

Once the cash flow accounting was supplemented with accrual accounting, new expenditure elements were added to the previous ones (summarized in the Statement regarding the execution of the accrued budget expenses - due to the application of the provisions of Order of Ministry of Public Finance no. 1746/2005): budgetary commitments, legal commitments and legal commitments to pay.

In terms of income, the addition refers to committed revenues, to the extinction in other ways than cashing in, without an annex where these elements are stipulated before implementing accrual accounting.

The income elements for which there is information are: own revenues (amounts received from the Ministry of Education as basic funding, own revenues from taxes and activities run by higher education institutions, donations and sponsorships, incomes from provided services), revenues from scientific research activities, projects, consultancy, expertise, budget allocations for special purposes, revenues from micro-production, experimental teaching activities, botanical gardens; own revenues of dorms and canteens, non-reimbursable external funds, sponsorships.

In terms of expenditure, we have: expenses with basic activity (expenses from own revenues and from the basic funding), expenses with the scientific research activity, projects, consultancy, expertise; expenses from budget allocations for special purposes, micro-production expenses, experimental teaching activities, botanical gardens; expenses for dorms and canteens, expenses from non-reimbursable external funds and sponsorships.

Cash flow statement. Cash has undeniable advantages and continues to be very important because without it, providing quality and complete public services is not possible. The legal framework (OMPF no. 1917/2005) provides very little information about this component of financial statements compared with IPSAS 2 "Cash flow statements", which details its role in obtaining information useful for accounting, as well as for decision-making.

In this statement, cash is structured depending on the nature of the activity run by the higher education institution: operational activity, investment activity and financing activity.

The information regarding cash flows allows the users to establish how the entity in the public sector generates the cash necessary to support the activity and how this cash is used.

A unit that prepares and presents a financial statement based on accrual accounting must also prepare a cash flow statement and present it as an integral part of the financial statement in each period for which these statements are presented.

The information about cash flows may be useful for the users of financial statements in:

- assessing the cash flows of the entity;

- assessing the unit in accordance with the adopted legislation and rules (including the authorized budget that was allocated);

- making decisions regarding the resources' supply;

- making or not making certain transactions. 
The cash flow statements contribute to ensuring comparability between achieved performances, eliminating the effects of using different accounting treatments for the same type of transactions and events.

In making and assessing decisions about the allotment of resources, the users need to understand the timing and certainty of cash flows.

It should be mentioned that cash flows constitute the advantage of cash accounting compared to accrual accounting, even if the latter is preferred.

The third annual account - annex (term found in OMPF no. 1917/2005) is a conceptual product, contributing to the understanding of the balance sheet, of the earning account and of the budget execution account through the complementary it has with these accounts and through the explanation and comments related to the information generated by these accounting products. Beyond rendering some elements regarding the entity's statement, the annex is a fundamental document because of disclosing certain elements about the strategy of higher education institutions.

The justification of this annex as an integral part of the balance sheet is given by the need to augment information about the economic and financial statement, as well as about how budgetary resources were obtained and used in relation to the aimed objectives. Being an additional document, the current annex of financial statements includes the component specified in table no. 1.

The annex called "Synthetic indicators of the income and expenditure budget's execution" includes the following indicators: total revenues, total expenditure, the share of the amounts received from contracts with the Ministry of Education, Research, Youth and Sports in total revenues, coverage of expenses from other sources apart from the ministry, the average cost per student.

The "report regarding the financial audit" refers to the operations with a financial impact over public funds or public patrimony, to the number and value of operations subjected to the financial audit visa, with refused visa and unexecuted as a result of the refusal.

"Statement regarding the execution of the employed expenditure budget" (namely, personnel expenses, material and services expenses, transfers, capital expenses) specifies the employed budgetary appropriations, budgetary appropriations, available budgetary appropriations, legal commitments, associated payments, actual expenses, which are all elements found in the budgetary execution account prepared according to accrual accounting.

"Detailed expenses" are presented according to the economic classification (total expenditure from own revenues and from the basic funding, expenses with the scientific research activity, projects, expertise; expenses from budget allocations for special purposes, microproduction expenses, experimental teaching activities, botanical gardens; expenses for dorms and canteens, expenses from funds allotted by the ministry from external sources).

According to IPSAS 1 "Presentation of financial statements", the notes to financial statements can be narrative descriptions or detailed analyses of the values presented in: financial performance statement, financial situation statement, cash flow statements, statement of changes in net assets/equity, as well as additional information about contingent assets and commitments.

Accounting policies are specific principles, norms, conventions, rules and practices adopted by a unit in order to prepare and present financial statements. Significant accounting policies must describe the assessment base used to recognise elements of assets and debts, potential government subsidies, forecasts (which are made by management and concern the determination of the assets and debts' values, the highlighting of debts and contingent assets, the variation of the real results compared to estimates), contingencies (their existence will be confirmed by the emergence of uncertain future events, which can't be completely under the control of public institutions).

Recognizing the depreciation of assets, the possibility to create provisions for debts based on the principle of prudence and the independence principle have become mandatory in accrual accounting. 
The accurate preparation of financial statements leads to supplying complete information that reflects the reality of how the activity unfolded within institutions of higher education, and also leads to making a comparison with the activity of the previous financial year. It is imperative to prepare financial statements on time, given their centralization at the level of the main credit release authority and the special importance in providing information needed to substantiate the budget for the next accounting period. Essentially, financial statements recompose the life of universities through calculations at the end of each period.

In the end, we subscribe to the theory according to which "in order to have a financial communication that will satisfy the interests of all parties, the accounting rules must reach a compromise" (E. Chiapello quoted by M. Berheci, 2010)

\section{Conclusions}

Financial statements are a communication mean in the economic and financial world that surrounds us.

Although there are arguments in favour of both accounting models (cash and accrual), the accounting profession agrees that, currently, accrual accounting is the best answer to today's requirements of the entities and users of accounting information.

The information generated by cash accounting has advantages, such as: the possibility to use it for forecasts regarding encashment and payments; it doesn't contain significant errors given the rigid legal patterns, it materializes in a depiction of the cash flows, which is useful in explaining the entity's performances in generating cash. Nevertheless, sometimes all this information is difficult to understand and is not complete, being aimed only at past transactions and it doesn't allow the continuous measurement of the "numeric" performances of the entity.

The information supplied by accrual accounting also provides the forecasting opportunity of encashment and payments, being completely and intelligibly presented, which facilitates their use in substantiating decisions. At the same time, accrual accounting adds new components to the structure of financial statements prepared by universities: earnings account, cash flow statement, statement of changes in net assets/equity, and the annexes include, among others, accounting policies. We shouldn't neglect the promotion of professional reasoning and the elimination of the restrictive nature of using the technical tools of accounting, as well as the explanatory notes to financial statements..

All these changes bring closer the financial reporting in the public sector to the reporting used in the private sector, but also to the provisions of the international accounting standards.

Beyond these remarks, it may be stated that regardless of the used basis of accounting, the picture provided by financial reporting is not unique given the wide range of users and their specific information needs.

We consider beneficial the complementarity of the two accounting forms for reasons that pertaining to providing information that will meet all the quality features, including comparability with other entities, increased accountability of credit release authorities, increased transparency of public information, emphasis on the features of each public institution with the help of the indications in the budgetary execution account, etc.

We noticed a growth in the quality of information by supplementing cash accounting with accrual accounting, but some improvements may still be made, especially in the case of universities, where performance should be measured in non-financial terms also.

In the future, it's not ruled out to supplement the information included in financial reporting with elements regarding the ability of universities to adapt to the continuously changing environment: identifying and mitigating risks justifying quality not only through the indicators related to scientific research, but also by relating to the education receivers and to the insertion level of graduates on the labour market, assessing human resources, which is even more necessary given that in this area the quality of human resources impacts future generations. Analyzing commitments 
in settlement accounts with the education receivers, in terms of the theoretical underlying and the process of putting it into practice, may lead to other elements related to filling out the financial reports of higher education institutions.

\section{References}

1. Berheci M., 2010. Valorificarea raportărilor financiare, CECCAR Publishing House, Bucharest, pp. 9, 18, 74.

2. Bolos I.M., 2006. Bugetul şi contabilitatea comunităţilor locale - între starea actuală şi posibilitățile de modernizare, Economica Publishing House, Bucharest, pp. 301, 323, 333.

3. Bota Avram F., 2009. Imaginea fidelă în contabilitate, Risoprint Publishing House, Cluj Napoca, pp261-268.

4. Dragan C.M, 2001, Contabilitatea instituţiilor şi administraţiei publice, Contconsult The European Audit Publishing House, Bucuresti, p.223.

5. Hlaciuc E., Mihalciuc C., Apetri A., 2008. Financial Comunication through the Financial Statements According to the International Accounting Settlements, http://www.oeconomica.uab.ro/upload/lucrari/1020081/19.pdf, (18.01.2011).

6. Feleaga N., Malciu L., 2002. Politici si opțiuni contabile, Economică Publishing House, Bucharest, p. 61.

7. Horomnea E., 2008. Fundamentele ştiințifice ale contabilității, Tipo Moldova Publishing House, Iaşi, p. 229.

8. Matis D., Pop, A. et. al. 2007. Contabilitate financiară, Alma Mater Publishing House, ClujNapoca, p. 702.

9. Matis D. et. al, 2005. Bazele contabilității, Alma Mater Publishing House, Cluj-Napoca, 347.

10. Profiroiu A., 2001. Pilotajul serviciilor publice, Economica Publishing House, Bucharest, pp. 12, 19.

11. Ristea M., 2005. Contabilitate financiară, Universitară Publishing House, Bucharest, p. 17.

12. Rusu D., 1980. Bazele contabilităţii, Didactica şi Pedagogică Publishing House, Bucharest, pp. $253,347$.

13. Todea N., 2009. Teorie contabilă şi raportare financiară, Aeternitas Publishing House, Alba Iulia, p. 133.

14. IFAC, 2009. Manual de standarde internaționale de contabilitate pentru sectorul public, CECCAR Publishing House, Bucharest.

15. National Education Law no. 1 of January 5, 2011, Official Gazette no. 18 of 10.01.2011.

16. Accounting law no. 82/1991 republished, Official Gazette no. 454 of 10.01.2008.

17. The Order of the Ministry of Public Finance no. 1917 of December 12, 2005 for the approval of the Methodological norms regarding the organization and the management of the accounting of the public institutions patrimony, of the accounts plan for the public institutions and the monograph regarding the registration in accounting of the main operations, Official Gazette no 1186 bis from 29.12.2005, with the following changes and.

18. http://www.ifrs.org/

19. http://www.accountingcoach.com 